\title{
Applying a spread model to identify the entry points from which the pine wood nematode, the vector of pine wilt disease, would spread most rapidly across Europe
}

\author{
Christelle Robinet • Nico Van Opstal • \\ Richard Baker $\cdot$ Alain Roques
}

Received: 14 April 2010/Accepted: 10 March 2011/Published online: 24 March 2011

(C) The Author(s) 2011. This article is published with open access at Springerlink.com

\begin{abstract}
Pine wilt disease, which can rapidly kill pines, is caused by the pine wood nematode, Bursaphelenchus xylophilus. It is expanding its range in many countries in Asia and measures are being taken at the EU level to prevent its spread from Portugal. Due to the threat to European forests, it is important to prevent additional introductions and target surveillance to the points of entry that pose the greatest risk. In this study, we present a model to identify the European ports from which the nematode can spread most rapidly across Europe. This model describes: (1) the potential spread of the pine wood nematode based on short-distance spread (the active flight of the vector beetles) and long-distance spread (primarily due to human-mediated transportation), and (2) the
\end{abstract}

Electronic supplementary material The online version of this article (doi:10.1007/s10530-011-9983-0) contains supplementary material, which is available to authorized users.

C. Robinet · A. Roques $(\bowtie)$

INRA UR633 Zoologie Forestière,

2163 Avenue de la pomme de pin,

CS 40001, Ardon, 45075 Orleans Cedex 2, France

e-mail: alain.roques@orleans.inra.fr

N. Van Opstal

European and Mediterranean Plant Protection

Organization, 21 boulevard Richard-Lenoir,

75011 Paris, France

R. Baker

The Food and Environment Research Agency,

Sand Hutton, York YO41 1LZ, UK development of pine wilt disease based on climate suitability and the potential spread of the nematode. Separate introductions at 200 European ports were simulated under various climate change scenarios. We found that the pine wood nematode could invade $19-60 \%$ of the study area $\left(30^{\circ} 00 \mathrm{~N}-72^{\circ} 00 \mathrm{~N}\right.$, $\left.25^{\circ} 00 \mathrm{~W}-40^{\circ} 00 \mathrm{E}\right)$ by 2030 , with the highest spread from ports located in Eastern and Northern Europe. Based on climate change scenarios, the disease could affect $8-34 \%$ of the study area by 2030 , with the highest spread from ports located in South-Eastern Europe. This study illustrates how a spread model can be used to determine the critical points of entry for invasive species, so that surveillance can be targeted more accurately and control measures prioritised.

Keywords Accidental introduction - Climate change $\cdot$ Human activities $\cdot$ Invasion $\cdot$ Nematode

\section{Introduction}

Given the increasing number of alien species introduced to different parts of the world, and their environmental and economic impacts (Pimentel et al. 2005; Work et al. 2005; Hulme et al. 2009a, b; Roques et al. 2009), understanding the mechanisms of biological invasions has become an important issue. Approximately 1,300 alien terrestrial invertebrate species are now established in Europe, representing one of the most numerous groups of 
organisms (Roques et al. 2009). Thus it is important to provide estimates of the potential risk of invasions of alien species, and propose solutions appropriate to the state of invasion, e.g. to target phytosanitary measures to the most risky pathways to prevent entry (see Phytosanitary Measures PM 9/1(3) and PM 9/10(1) from the European and Mediterranean Plant Protection Organization, EPPO, http://archives.eppo.org/ EPPOStandards/regulatorysystems.htm), or apply containment and eradication measures to stop establishment and spread of the invasion (see Liebhold and Tobin 2008 for a review of the most appropriate methods).

Bioclimatic models based on climate matching using presence-absence data are often used to determine the potential distribution of a species (Guisan and Zimmermann 2000; Kriticos and Randall 2001; Elith et al. 2006). Although true absence data are essential in distribution models (Václavík and Meentemeyer 2009), they are sometimes not available and generating pseudo-absence data can induce some errors in the models (e.g., Elith and Leathwick 2009, Lobo et al. 2010). This concern is even greater for invasive alien species that are still spreading since absence data may be misleading. In this case, distribution models can be developed in combination with some dispersal constraints (e.g., Meentemeyer et al. 2008; Roura-Pascual et al. 2009). An important factor in estimating the potential risk of expansion of an invasive species is the dispersal ability of individuals. Previous studies have mainly focussed on natural spread, e.g. the ability of the species or its vector to disperse by itself or passively by wind, with models based on a random diffusion process, generating a travelling wave with a constant asymptotic speed (Shigesada and Kawasaki 1997; Murray 2002). However, possible long distance jumps combined with short-distance movements, so-called stratified dispersal, can significantly increase the speed of expansion (Shigesada and Kawasaki 1997; Liebhold and Tobin 2008). Increasingly, studies have shown that human-mediated dispersal plays an important role in the long-distance dispersal of invasive terrestrial invertebrates (e.g., Gilbert et al. 2004; Muirhead et al. 2006; Lippitt et al. 2008; Pitt et al. 2009; Robinet et al. 2009). Since these long-distance jumps have a low probability of occurrence and are difficult to predict, the most appropriate models to describe this type of spread are stochastic although hundreds of replicate simulations may be required to obtain a representative estimate of potential spread (Pitt et al. 2009; Robinet et al. 2009).

The pine wood nematode, Bursaphelenchus xylophilus (Steiner and Buhrer) Nickle, is usually considered to be a secondary pathogen in stressed or recently dead trees in North America, its native area (Bergdahl 1988). However, it causes severe damage to Pinus trees in countries where it has been introduced in Asia (Japan, China, Taïwan, South Korea) (Togashi and Shigesada 2006). The nematode, or more precisely, the pine wilt disease transmitted by the nematode, has already caused the death of millions of pines. In Japan, despite control efforts, the volume of damaged timber had reached 2.4 million $\mathrm{m}^{3}$ per year and 500,000 ha of pine forest was infested by the 1980's (Mamiya 1984). Pine wilt disease is one of the major forest threats to Europe because of its devastating impacts on host trees and the difficulties in containing its spread and eradicating the nematode after introduction (Evans et al. 1996; Suzuki 2002; Pérez et al. 2008; Økland et al. 2010). Pine wilt disease was discovered in Portugal in 1999 in the Setúbal Peninsula (Mota et al. 1999) and, in spite of strict control and containment measures, it spread approximately $150 \mathrm{~km}$ northward in 2008-2009 and now infests a major part of the country (Mota et al. 2009).

The pine wood nematode is transmitted between trees by long-horn beetles of the genus Monochamus (Coleoptera: Cerambycidae) over relatively short distances. It is often detected close to port areas (Mota et al. 2009) because of the human transportation of infested material, notably wood packaging. Accidental transportation by humans can effectively spread the beetles and the nematodes over long distances. Seasonal drought and high temperature causing water stress in the host trees plays an important role in disease development (Anonymous 2007; Evans et al. 2008). Due to the increase in the mean global temperature predicted by climate scenarios $\left(+1.8-4.0^{\circ} \mathrm{C}\right.$ between 1980-1999 and 2090-2099; Meehl et al. 2007), it is important to predict the effects of climate change on the invasion risk. Decision makers in Europe need estimates of the invasion risk of pine wood nematode and pine wilt disease in Europe to define, as soon as possible, effective surveillance and control measures. 
Here we present a model to determine the European ports from which the nematode and the wilt disease can spread most rapidly across Europe if introduced. This model describes the potential spread of the pine wood nematode and pine wilt disease throughout Europe under current and future climates. We considered separate introductions at 200 European ports in addition to the spread of the existing Portuguese populations to identify the entry points which are the most important to control. This model, derived from the model of expansion of the pine wood nematode in China (Robinet et al. 2009), describes (1) the potential spread of the pine wood nematode in Europe based on short-distance spread (active flight of the vector beetles) and long-distance spread (primarily due to human-mediated transportation) taking into account a proxy for the abundance of susceptible trees; and (2) the potential future development of pine wilt disease based on climate suitability and the potential spread of the nematode. Although the mechanism for disease expression is not fully understood, the mean temperature in July is widely considered in the literature to be the main driver (e.g., Rutherford and Webster 1987; Evans et al. 1996; Pérez et al. 2008). Based on the temperature constraint (temperature in July above $20^{\circ} \mathrm{C}$ ), we compare predictions under current climate based on 1950-2000 temperatures, and three global climate change scenarios (A1, A2 and B2; IPCC 2007).

\section{Materials and methods}

Study system (disease, nematode and vector)

The pine wilt disease develops in susceptible species of Pinus under suitable climatic conditions (high summer temperature and drought), and the infected tree can wilt and die within weeks of being infested. This disease is transmitted by the pine wood nematodes, but the presence of the nematode in a tree does not necessarily produce the symptoms of pine wilt disease.

The pine wood nematodes are transmitted by longhorn beetles of the genus Monochamus during the feeding of the adult insects (maturation feeding by either sex), or during oviposition by the females. Various Monochamus species can carry B.xylophilus, particularly M. carolinensis (Olivier) in North America (Dropkin et al. 1981; Linit et al. 1983; Linit 1988), M. alternatus (Hope) in infested regions of Asia (Mamiya 1972; Lee et al. 1990; Chang et al. 1995; Yang 2004) and M. galloprovincialis (Olivier) in Portugal (Evans et al. 1996; Sousa et al. 2001; Sousa et al. 2002; Penas et al. 2006). The latter species is mostly found on pine trees in southwestern Europe and North Africa but it also occurs in North and Central Europe (Hellrigl 1971, see also http://www.faunaeur.org/). Other Monochamus spp. are also potentially able to carry the nematode, especially in continental Europe. However, no potential vector is present in the United Kingdom and Ireland.

Distribution of the pine wood nematode and containment measures in Portugal

Symptoms of pine wilt disease were discovered in Portugal in 1999, and the presence of B. xylophilus was confirmed. Maritime pine (Pinus pinaster Aiton) trees infected by pine wilt disease were discovered at two sites in Portugal: Marateca/Pegoes and Vale de Landeira (Mota et al. 1999), located approximately $3 \mathrm{~km}$ from each other in the area of Setúbal.

As soon as the pine wood nematode was detected, some containment measures were immediately applied through the National Eradication Programme for the Pinewood Nematode Control (PROLUNG). The affected zone (currently covering 510,000 ha) and a buffer zone of $20 \mathrm{~km}$ width (currently covering $500,000 \mathrm{ha}$ ) was delimited and adjusted over the years according to disease spread (Rodrigues 2008). Periodic surveys, eradication and insect vector control actions are being conducted on the whole affected and buffer zone (known as the demarcated area). Forestry activities related to conifers are intensively controlled (felling and transport permits are needed) and symptomatic trees are cut and destroyed in the demarcated area. A survey is also conducted in the free zone and some materials are collected to test the presence of the pine wood nematode (see Rodrigues 2008 for further details). In 2007, all coniferous hosts were eliminated within a clear cut belt ( $3 \mathrm{~km}$ wide, currently covering $130,000 \mathrm{ha})$ to prevent further spread. In addition, some traps have been installed along the outer limit of the affected zone to capture the vector during its flight period. 
Despite the immediate application of containment measures, the disease has not been successfully contained and newly infested stands were observed in other parts of Portugal (Mota et al. 2009). In 2008, the pine wood nematode was found at 65 of the 2,443 Portuguese locations surveyed (source: Ministry of Agriculture, Portugal, unpublished report). Infestations were mainly recorded in the central part of the country (near Lousa) at more than $150 \mathrm{~km}$ from the initial location in the Setúbal Peninsula. The pine wood nematode has also been detected in Spain in November 2008 in a single tree (at around $50 \mathrm{~km}$ from the border with Portugal; eradicated) and in December 2010 in seven trees in Galicia (at $5 \mathrm{~km}$ from the border). Since we have only incomplete information of the latest Spanish outbreak, we did not include this location in this study and only considered the Portuguese distribution in 2008 as the initial population for the model.

\section{Limiting factors}

In China, Robinet et al. (2009) used the climatic constraints defined for the vector, M. alternatus, i.e. a July mean temperature of $\geq 21.3^{\circ} \mathrm{C}$ and January mean temperature of $\geq-10^{\circ} \mathrm{C}$ (Kobayashi et al. 1984; Ma et al. 2006), to predict the potential distribution of the pine wood nematode. As mentioned previously, other potential Monochamus vector species exist in most of Europe, apart from the UK and Ireland. The pine wood nematode can survive without food and in conditions of severe drought and cold (Mamiya 1972, 1984) and therefore, assuming suitable hosts and vectors are present, could probably establish in large parts of Europe. However, the disease has apparently never occurred where the mean air temperature of the warmest month was below $20^{\circ} \mathrm{C}$ (Rutherford and Webster 1987; Rutherford et al. 1990; Pérez et al. 2008). Consequently, the main limiting factor in terms of climate is associated with pine wilt disease expression in Europe. Although, drought is also implicated, the relationship with disease expression is poorly known and we therefore only modelled temperature.

The second important limiting factor is the capability for spread. Although it is an important factor, we have little information about the dispersal ability of the European vector species. The dispersal limits for the North American vector, M. carolinensis and the Asian vector, $M$. alternatus, are considered to be around $2-3 \mathrm{~km}(1.8 \mathrm{~km}$ in Takasu et al. 2000, greater than $2 \mathrm{~km}$ in Linit and Akbulut 2003 and $3.3 \mathrm{~km}$ in Kawabata 1979). The spread rate of the infestation is greater than this, probably because of the combination of various factors, such as natural and humanassisted dispersal. The spread rate was estimated to 2-15 km per year in Japan (Togashi and Shigesada 2006) and $7.5 \mathrm{~km}$ per year in China (Robinet et al. 2009). Several factors, such as susceptible host tree density, vector beetle density, nematode density carried by the beetles, maximum air temperature and wind can affect the dispersal ability of the beetles (Humphry and Linit 1989; Togashi 1990; Lai 1998; Lai et al. 1999; Linit and Akbulut 2003). In addition to short distance spread, pine wilt disease can also be introduced several hundred kilometres from previously infested areas through the accidental transport of infested material by man (Robinet et al. 2009). Human population density was found to be a good indicator for the risk of human assisted transportation of the pine wood nematode (Robinet et al. 2009) and other insect species e.g., the horse chestnut leafminer, Cameraria ohridella (Gilbert et al. 2004) and the emerald ash borer, Agrilus planipennis (Muirhead et al. 2006).

\section{Modeling approach}

Until now, models have mainly focussed either on small-scale dispersal mechanism without considering the climatic constraint for the disease expression (e.g., in Japan; Takasu et al. 2000; Takasu 2009) or on small-scale mechanism for the disease expression without considering the dispersal capabilities (Iberian Peninsula; Anonymous 2007; Evans et al. 2008; Pérez et al. 2008). A first model to assess the probability of detection and eradication was developed for South-East Norway (Økland et al. 2010). This model, derived from the small-scale dispersal model developed in Japan, is aimed at tracking the trees virtually infested by the pine wood nematode. Although many parameters are still unknown about the spread of the nematode, the vector beetles, and the disease in Europe, the challenge is now to provide predictions about the potential spread of the nematode and the disease at the European scale.

We modified the large-scale model describing the spread of the symptoms in China (Robinet et al. 2009) 
to take into account the proportion of land covered by pines to calculate the proportion of infested area and proportion of host trees infested in 2030 assuming no control action (Fig. 1). This model was implemented in $\mathrm{R}$ ( $\mathrm{R}$ Development Core Team 2009), on grid cells $(500 \times 450$ cells, with a cell size $\Delta x=\Delta y=10 \mathrm{~km})$ covering our study area $\left(30^{\circ} 00 \mathrm{~N}-72^{\circ} 00 \mathrm{~N}, 25^{\circ} 00 \mathrm{~W}\right.$ $\left.-40^{\circ} 00 \mathrm{E}\right)$. For the initial conditions, we considered that $N_{0} \%$ of susceptible trees were infested at the 65 infested locations in 2008. We then derived the proportion of initially infested area based on this value and the proportion of the area covered by susceptible trees (within each cell). Then, for each time $t$ from 2009 to 2030, we applied a reactiondiffusion model which describes the spread of the carrier beetles and a stochastic model combining a dispersal kernel and a function of the human population density which describes the human-mediated spread (Fig. 1a). Two different kernels were used to describe human-mediated dispersal in China (because two different patterns were observed in the field), one to describe the dispersal before 2001 and the other for the dispersal after 2001 when human-assisted spread was much more important. In Europe, we used the second kernel to model the role played by humanassisted spread because it takes current trade activity into account. When the model predicted dispersal in a cell without Pinus, we considered that the pine wood nematode could not survive in this cell. We made 200 replicate simulations to obtain a representative output of the model for each scenario (Fig. 1b, see Appendix S1) and calculated the mean proportion of the area infested $(N)$ and the mean number of host trees infested $(I)$ over these 200 replicate simulations, for each cell. These results give the potential spread of the pine wood nematode. The spread of the pine wilt disease was considered to be the same as the potential spread of the nematode with the exception that the spread is considered to be impossible where the mean temperature in July $(\mathrm{TJ} u l)$ is below $20^{\circ} \mathrm{C}(N=I=0$ in this case) (Fig. 1b). The outputs were summarised as follows for each scenario: the mean proportion of the area infested $\left(N_{m}\right)$, the mean proportion of host trees infested $\left(I_{m}\right)$, the percentage of cells where the proportion of infested area $N$ was greater than $0,0.25$, 0.50 and $0.75\left(P N_{0}, P N_{25}, P N_{50}\right.$ and $P N_{75}$ respectively) and the percentage of cells where the proportion of infested host trees $I$ was greater $0,0.25,0.50$ and $0.75\left(P I_{0}, P I_{25}, P I_{50}\right.$ and $P I_{75}$ respectively).
These means and percentages were calculated over all the cells.

To evaluate the robustness of the model, we undertook a sensitivity analysis on the principal parameters when modelling spread from Portugal (Table 1). The values used in this study were derived from the study in China (Robinet et al. 2009), except for $N_{0}$ (a new parameter). For the previous parameters, we tested the effects of a $10 \%$ increase and decrease. We calculated the difference in the model outputs. For $N_{0}$, information was available only for a few locations near Setúbal between 1999/2000 and 2006/2007 (Rodrigues 2008). In this study we used the value reported for these locations in the first year of their discovery (around 20\%). We tested a large range of values $(1,20,40,60$, and $80 \%)$ for the sensitivity analysis and calculated the resulting difference in the model outputs.

\section{Description of the datasets}

\section{Host tree distribution}

In Portugal, pine wood nematode and pine wilt disease were detected on Pinus pinaster (Mota et al. 1999) but many Pinus spp. are potentially susceptible to the disease (Evans et al. 1996). Cedrus spp., Larix decidua and Picea abies Karsten are also potential host trees in Euro-mediterranean countries (Evans et al. 1996). For simplification, we considered that all European Pinus species are potential hosts. The European Forest Institute provided a GIS map of the proportion of Pinus in the total land area at a resolution of $1 \times 1 \mathrm{~km}$ (see Tröltzsch et al. 2009 for further details) (Fig. 2a).

\section{Human-population density}

The distribution of human population in 2005 was taken from the Gridded Population of the World, version 3, with a 2.5' resolution (Center for International Earth Science Information Network (CIESIN), Centro Internacional de Agricultura Tropical (CIAT) 2005; Fig. 2b). As previously mentioned, human population density is assumed to be a good indicator of the risk for the accidental transport of infested material. These density values were used as inputs for the formula used by Robinet et al. (2009) to calculate 
Fig. 1 a Description of the model algorithm and $\mathbf{b}$ the method to calculate the potential spread of the pine wood nematode and the pine wilt disease (a)

Algorithm of the spread model used for the pine wood nematode in Europe

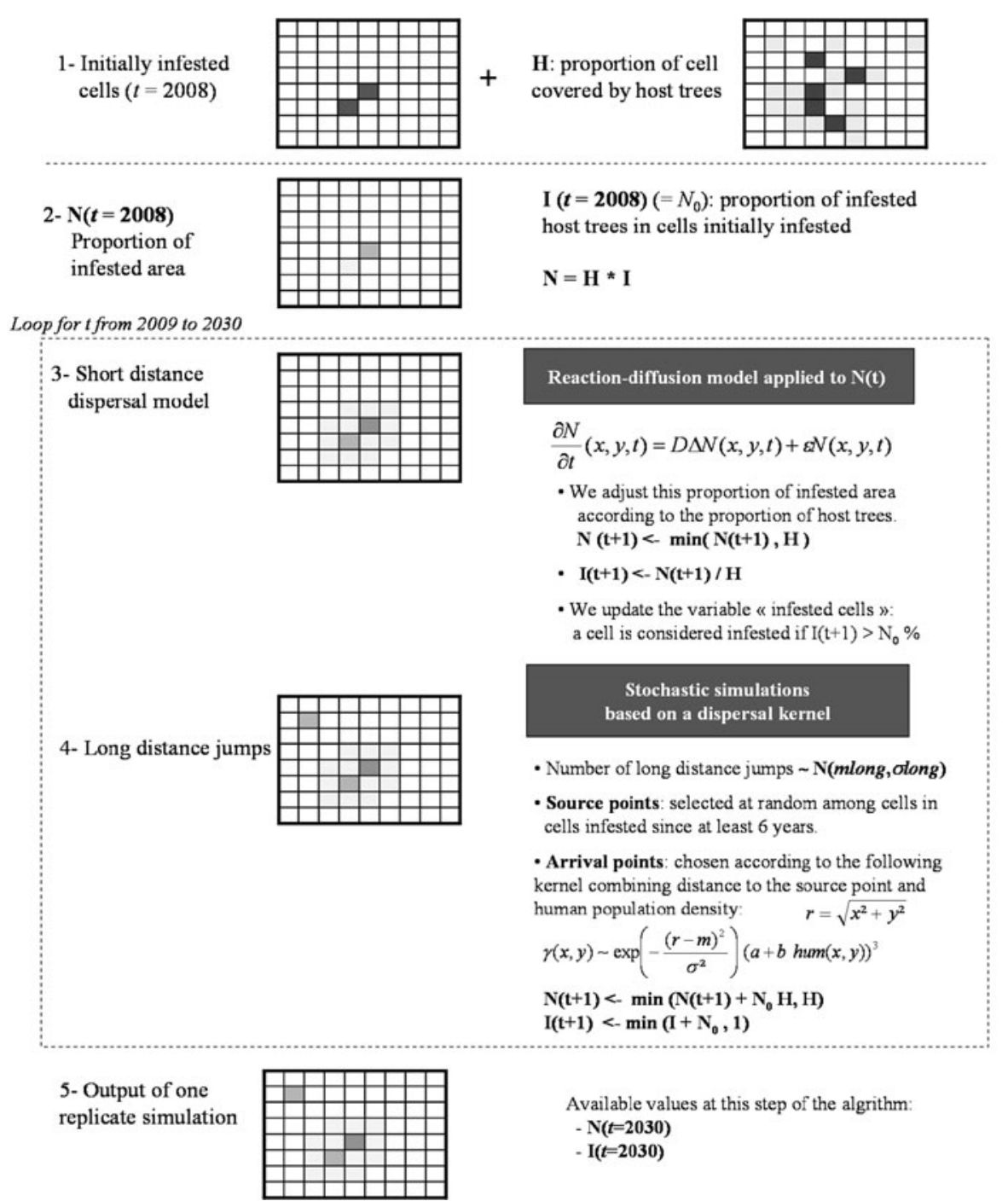

the probability that the nematode is transported to a given location (Fig. 1a).

Testing several climate scenarios

We tested four scenarios: current climate, represented by mean temperature in July for 1950-2000, and three HadCM3 climate change scenarios for the 2020s (A1, A2 and B2). The mean temperature in July currently ranges from 0.8 to $28.2^{\circ} \mathrm{C}$ in the study area, with an average of $17.7^{\circ} \mathrm{C}$. Temperatures were on average $1.7^{\circ} \mathrm{C}$ higher than the current scenario in the $\mathrm{A} 1$ scenario, $1.1^{\circ} \mathrm{C}$ higher in the $\mathrm{A} 2$ scenario and $1.5^{\circ} \mathrm{C}$ higher in the $\mathrm{B} 2$ scenario.

Historical gridded temperature data were downloaded from http://www.worldclim.org/ (Hijmans et al. 2005), and climate scenarios from http://gisweb. ciat.cgiar.org/GCMPage/ (accessed on January 6th, 2011). We tested the climate scenarios A2 and B2 (2020s) using the HCCPR-HADCM3 model and the A1 
Fig. 1 continued

(b) Calculation of the potential spread of the pine wood nematode and pine wilt disease

A. Loop on the number of replicate simulations: repeat 200 times the steps 1-5.
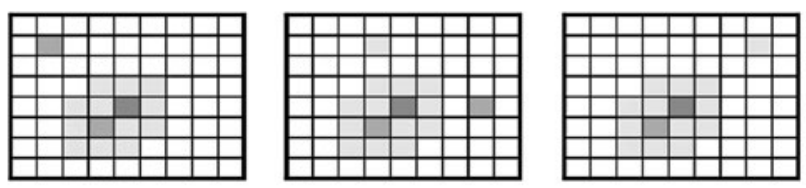

B. Calculate $I_{\mathbf{2 0 0}}(t=2030)$ the mean proportion of infested host trees $I(t=2030)$ and $\mathbf{N}_{\mathbf{2 0 0}}(t=\mathbf{2 0 3 0}$ the mean proportion of infested area $\mathrm{N}(\mathrm{t}=2030)$, in each cell over the 200 replicate simulations

\section{Potential spread risk of the pine wood nematode}

C. Combine this layer B with suitable climate for the disease expression

If the mean temperature in July $\geq 20^{\circ} \mathrm{C}$, then $\mathbf{N}_{\mathrm{D}, \mathbf{2 0 0}}=\mathrm{N}_{200}$ and $\mathbf{I}_{\mathrm{D}, \mathbf{2 0 0}}=\mathrm{I}_{200}$, otherwise $\mathrm{N}_{\mathrm{D}, 200}=0$ and $\mathrm{I}_{\mathrm{D}, 200}=0$.

\section{Potential spread of the pine wilt disease}

D. Some summary outputs are calculated for the pinewood nematode and pine wilt disease:

- $\mathbf{N m}=$ mean $\left(\mathrm{N}_{200}(t=2030)\right)$ over the grid

- $\operatorname{Im}=\operatorname{mean}\left(\mathrm{I}_{200}(t=2030)\right)$ over the grid

- PN0, PN25, PN50, PN75: the percentage of cells where $\mathrm{N}_{200}(t=2030)>0,0.25,0.50$ and 0.75

- PI0, PI25, PI50, PI75: the percentage of cells where $\mathrm{I}_{200}(t=2030)>0,0.25,0.50$ and 0.75
Table 1 Description of the parameters used in the model and the values used for the predictions

\begin{tabular}{lll}
\hline Parameter & Description & Value \\
\hline $\mathrm{D}$ & Diffusion coefficient & $6.480 \mathrm{~km}^{2} /$ year \\
$\varepsilon$ & Growth rate & 2.17 \\
$\mathrm{~m}$ & Mean dispersal distance & $377.22 \mathrm{~km}$ \\
$\sigma$ & SD of dispersal distance & $240.45 \mathrm{~km}$ \\
$\mathrm{~m}_{\text {long }}$ & Mean number of long distance jumps each year & 18.2 \\
$\sigma_{\text {long }}$ & SD of the number of long distance jumps each year & 5.89 \\
$\mathrm{~N}_{0}$ & Initial proportion of infested trees & $20 \%$ \\
\hline
\end{tabular}

scenario (2020s) using the UKMO-HADCM3 model at a resolution of $5 \mathrm{~min}$.

Testing entry in European ports

The pine wood nematode has been intercepted in packaging wood in many ports even in material coming from countries considered as non-infested (Mota et al. 2009). Therefore, maritime transportation is an important pathway for the nematode. Possible introductions via other means of transport (e.g. roads and railways) within Europe are taken into account by the long distance dispersal kernel because they connect highly populated areas. To identify the ports 

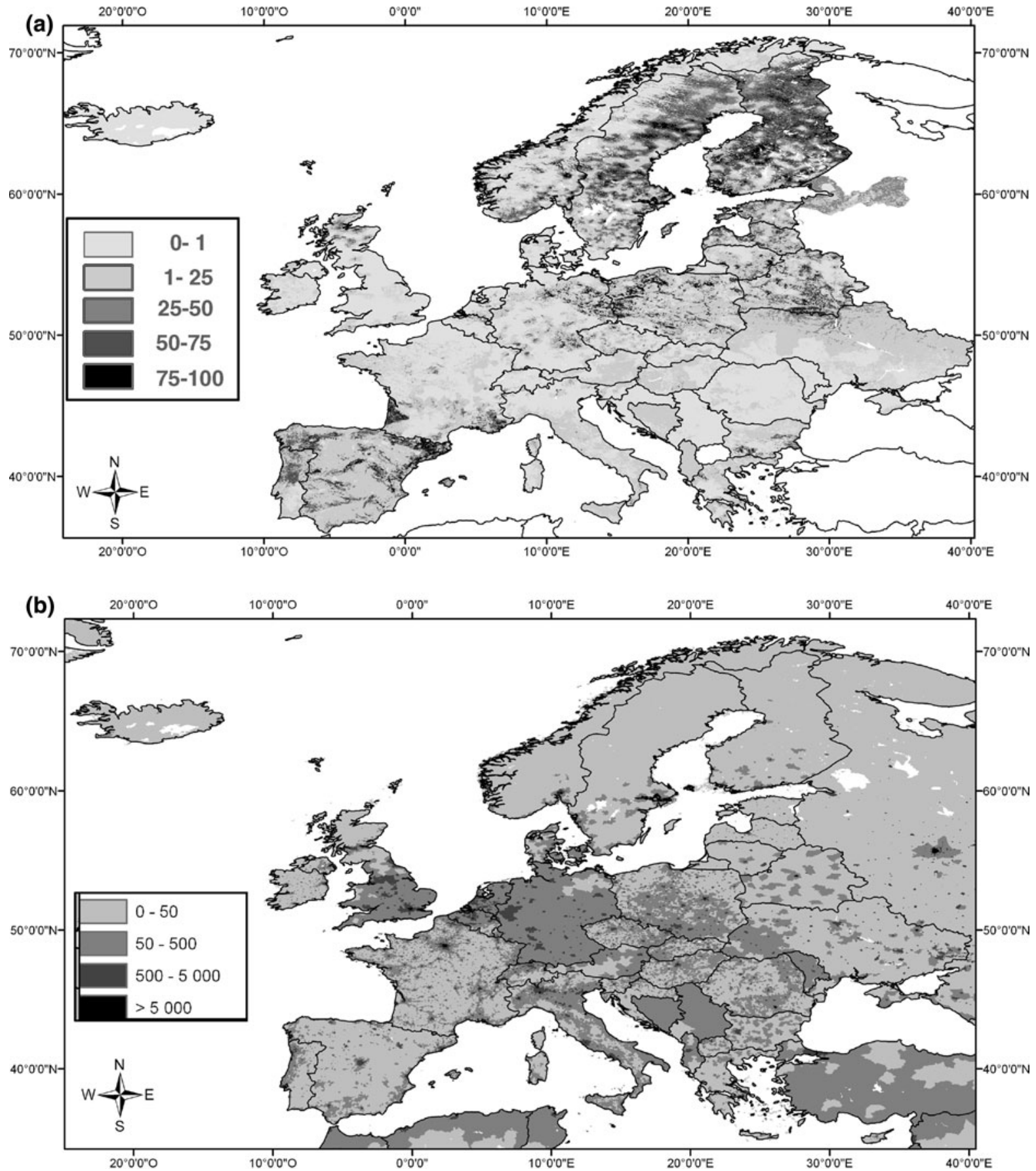

Fig. 2 a Host tree distribution (percentage of land covered by pines). b Human population density (number of inhabitants per km ${ }^{2}$ in 2000)

which require high priority surveillance to prevent the invasion of the pine wood nematode and wilt disease, we simulated the spread of the nematode in
2008 from the 200 largest European ports separately (source: http://www.worldportsource.com/), and from Portugal. 


\section{Results}

Model predictions

For all scenarios (no climate, current climate, A1, A2 and $\mathrm{B} 2$ scenarios), the largest variation $(8.5-57.7 \%)$ was obtained for $P N_{0}$ (the percentage of cells among the study area where the proportion of infested area is above 0 ) and $P I_{0}$ (the percentage of cells where the proportion of host trees is above 0 ). The other outputs varied by a much smaller amount (less than $0.8 \%$ ). Therefore, hereafter we consider only the variation in $P N_{0}$ (see the complete results in Appendix S2).

\section{Spread of the pine wood nematode (no climatic constraint)}

For the simulations made without climatic constraint, $19.3 \%$ (for Malaga, Spain) to $57.7 \%$ (for Budapest, Hungary) of cells could be infested $(N>0)$ by the pine wood nematode by 2030 (see Appendix S2). The principal ports from where the nematode could spread most rapidly were primarily located in Eastern and Northern Europe (see Fig. 3a). Introductions at some ports in Hungary, Slovakia, Russia, Poland, Croatia, Sweden, or Germany could result in nematode spread $(N>0)$ over more than $50 \%$ of the study area by 2030.

\section{Spread of the pine wilt disease (current climate)}

Under current climatic conditions, 8.5\% (La Coruña, Spain) to $21.7 \%$ (Constanta, Romania) of cells could be infested by the disease by 2030 (see Appendix S2). An introduction in some ports in Romania, Bulgaria, Croatia and Ukraine could have the greatest effect on disease spread across Europe (more than $20 \%$ of the study area would be infested) (Fig. 3b).

\section{Spread of the pine wilt disease (Al scenario)}

Under the A1 scenario, $14.2 \%$ (La Coruña, Spain) to $33.9 \%$ (Constanta, Romania) of cells could be infested by the disease by 2030 (see Appendix S2). An introduction to the ports in countries already identified under current climate conditions would have the greatest effect in addition to ports located in Hungary, Slovakia, Greece, Italy, Slovenia, Russia, Poland, Switzerland, Germany, France, Lithuania and
Latvia (more than $20 \%$ of the study area would be infested) (Fig. 3c).

\section{Spread of the pine wilt disease (A2 scenario)}

Under the A2 scenario, 9.9\% (La Coruña, Spain) to $28.1 \%$ (Constanta, Romania) of cells could be infested by the disease by 2030 (see Appendix S2). An introduction to the ports in countries already identified under current climate conditions would have the greatest effect in addition to ports located in Hungary, Greece, Italy, Slovakia, Slovenia (more than $20 \%$ of the study area would be infested) (Fig. 3d).

\section{Spread of the pine wilt disease (B2 scenario)}

Under the B2 scenario, $10.9 \%$ (La Coruña, Spain) to $30.9 \%$ (Constantza, Romania) of cells could be infested by the disease by 2030 (see Appendix S2). An introduction to the ports in countries already identified under current climate conditions would have the greatest effect in addition to ports located in Hungary, Slovakia, Greece, Italy, Slovenia, Russia, Poland (more than $20 \%$ of the study area would be infested) (Fig. 3e).

Sensitivity analysis

The difference observed in the mean proportion of infested area and infested host trees when using a large range of $N_{0}$ values (from 1 to $80 \%$ ) was less than 0.004 . The largest effect was observed for the percentage of cells where the proportion of infested host trees was above 0.75 , with a difference of around $3 \%$ (Table 2).

Among the other parameters, those associated with the long-distance dispersal kernel ( $m$ and $\sigma$ ) had the largest effects on the results, especially on the percentage of infested cells $(N>0$ or $I>0)$, with a difference of less than $3 \%$ (Table 2).

\section{Discussion}

Since the disease is only locally present in Europe and containment measures have been applied to stop the spread, it was not possible to use European data to analyse the spread pattern in Europe, identify the main 

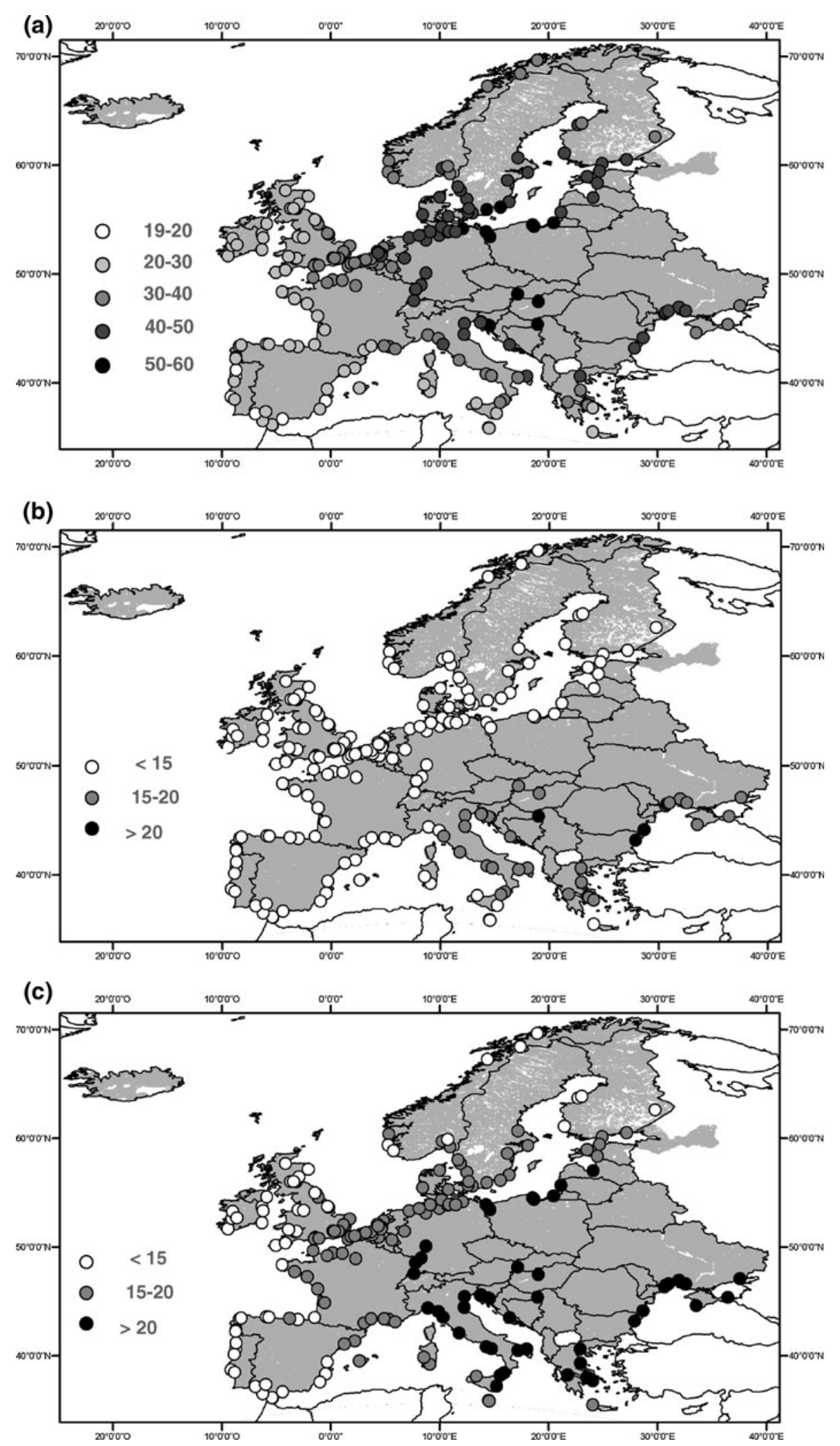
4Fig. 3 Potential spread in case of a separate introduction at the 200 main ports in Europe. The symbol indicates the percentage of cells where the infested area $N$ is above $0 \%$ in 2030 if the nematode was introduced at the port located there. a Spread of the pine wood nematode without climatic constraint. Spread of the pine wilt disease assuming: $\mathbf{b}$ a stable climate, $\mathbf{c}$ the A1 scenario, $\mathbf{d}$ the A2 scenario and e the B2 scenario. Area in grey is the study area

pathways, or even validate this model in Portugal. This model assumes that nothing is done or measures are unsuccessful in slowing the spread of pine wilt disease and eradicating new infestations because the objective of the study was to identify areas where symptom expression is likely to occur in order to concentrate control efforts on the most susceptible locations. We therefore used the parameter values for short and longdistance dispersal obtained when analysing the spread of pine wood nematode in China (Robinet et al. 2009). Although using the spread distance estimates from China may be subject to error, several factors show that these estimates are realistic. First, based on current knowledge, the maximum distances flown by the different vector species should be of the same order of magnitude (see the Pest Risk Analysis, PRA 09-15449, p. 29-30, http://www.eppo.org/QUARANTINE/Pest_ Risk_Analysis/PRA_documents.htm). Secondly, human activities may not facilitate the spread of the nematode in the same way in China and Europe. However, in the model, we do not use the absolute human population density. We consider the combination of a dispersal

Fig. 3 continued
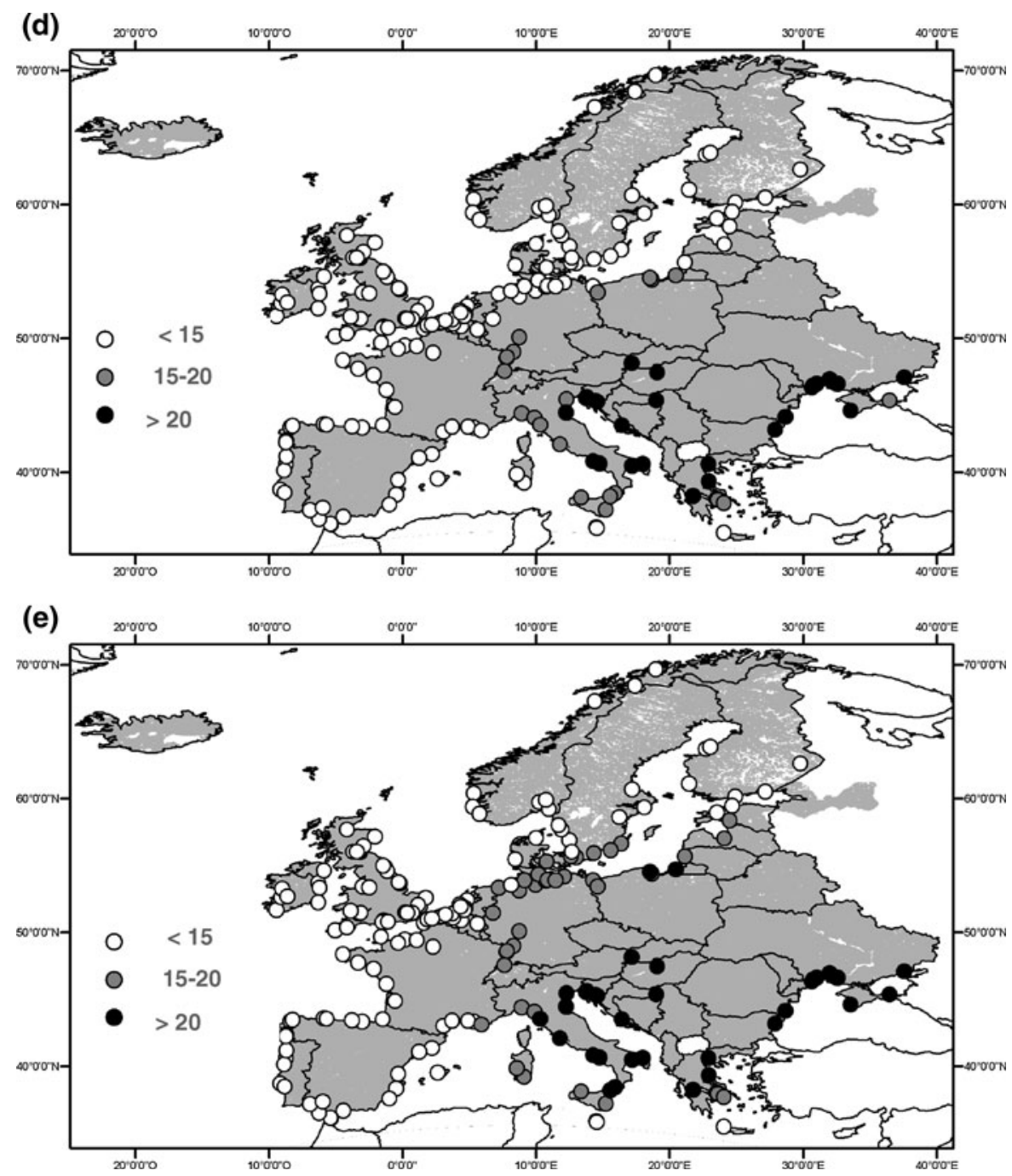
Table 2 Results of the sensitivity analysis

\begin{tabular}{|c|c|c|c|c|c|c|c|c|c|c|c|}
\hline Parameter & Value & $\mathrm{Nm}$ & $\mathrm{Im}$ & PNO & PN25 & PN50 & PN75 & PI0 & PI25 & PI50 & PI75 \\
\hline \multirow[t]{5}{*}{$\mathrm{N}_{0}$} & 1 & 0.003 & 0.015 & 20.3 & 1.1 & 0.1 & 0.0 & 20.3 & 8.7 & 6.3 & 1.4 \\
\hline & 20 & 0.003 & 0.018 & 19.6 & 1.4 & 0.1 & 0.0 & 19.6 & 9.1 & 7.5 & 3.4 \\
\hline & 40 & 0.003 & 0.018 & 20.3 & 1.5 & 0.1 & 0.0 & 20.3 & 9.2 & 7.8 & 4.1 \\
\hline & 60 & 0.004 & 0.019 & 20.5 & 1.6 & 0.1 & 0.0 & 20.5 & 9.2 & 7.9 & 4.6 \\
\hline & 80 & 0.004 & 0.019 & 20.3 & 1.6 & 0.1 & 0.0 & 20.3 & 9.2 & 7.9 & 4.8 \\
\hline \multicolumn{2}{|l|}{ Difference } & 0.001 & 0.004 & 0.9 & 0.5 & 0.0 & 0.0 & 0.9 & 0.5 & 1.6 & 3.4 \\
\hline \multirow[t]{2}{*}{ D } & 5.832 & 0.003 & 0.017 & 19.9 & 1.4 & 0.1 & 0.0 & 19.9 & 9.0 & 7.4 & 3.1 \\
\hline & 7.128 & 0.003 & 0.018 & 20.2 & 1.5 & 0.1 & 0.0 & 20.2 & 9.2 & 7.8 & 4.0 \\
\hline \multicolumn{2}{|l|}{ Difference } & 0.000 & 0.001 & 0.3 & 0.1 & 0.0 & 0.0 & 0.3 & 0.2 & 0.3 & 0.9 \\
\hline \multirow[t]{2}{*}{$\varepsilon$} & 1.953 & 0.003 & 0.017 & 21.3 & 1.4 & 0.1 & 0.0 & 21.3 & 9.0 & 7.4 & 3.0 \\
\hline & 2.387 & 0.003 & 0.018 & 20.1 & 1.5 & 0.1 & 0.0 & 20.1 & 9.1 & 7.8 & 4.1 \\
\hline \multicolumn{2}{|l|}{ Difference } & 0.000 & 0.001 & 1.2 & 0.2 & 0.0 & 0.0 & 1.2 & 0.1 & 0.4 & 1.2 \\
\hline \multirow[t]{2}{*}{$\mathrm{m}$} & 339.5 & 0.003 & 0.018 & 19.0 & 1.5 & 0.2 & 0.0 & 19.0 & 8.9 & 7.3 & 4.2 \\
\hline & 414.94 & 0.003 & 0.018 & 21.4 & 1.4 & 0.1 & 0.0 & 21.4 & 9.2 & 7.6 & 2.9 \\
\hline \multirow{3}{*}{$\begin{array}{c}\text { Difference } \\
\sigma\end{array}$} & & 0.000 & 0.000 & 2.4 & 0.1 & 0.0 & 0.0 & 2.4 & 0.4 & 0.3 & 1.3 \\
\hline & 216.405 & 0.003 & 0.018 & 18.7 & 1.5 & 0.1 & 0.0 & 18.7 & 8.8 & 7.4 & 4.2 \\
\hline & 264.495 & 0.003 & 0.018 & 21.4 & 1.4 & 0.1 & 0.0 & 21.4 & 9.3 & 7.9 & 2.8 \\
\hline \multicolumn{2}{|l|}{ Difference } & 0.000 & 0.000 & 2.7 & 0.1 & 0.0 & 0.0 & 2.7 & 0.5 & 0.4 & 1.3 \\
\hline \multirow[t]{2}{*}{$\mathrm{m}_{\text {long }}$} & 16.38 & 0.003 & 0.017 & 20.2 & 1.4 & 0.1 & 0.0 & 20.2 & 8.9 & 7.3 & 2.7 \\
\hline & 20.2 & 0.003 & 0.019 & 20.4 & 1.6 & 0.2 & 0.0 & 20.4 & 9.2 & 7.9 & 4.7 \\
\hline \multicolumn{2}{|l|}{ Difference } & 0.000 & 0.002 & 0.2 & 0.2 & 0.0 & 0.0 & 0.2 & 0.3 & 0.6 & 2.0 \\
\hline \multirow[t]{2}{*}{$\sigma_{\text {long }}$} & 5.301 & 0.003 & 0.018 & 20.2 & 1.4 & 0.1 & 0.0 & 20.2 & 9.1 & 7.6 & 3.6 \\
\hline & 6.479 & 0.003 & 0.018 & 20.6 & 1.5 & 0.1 & 0.0 & 20.6 & 9.0 & 7.6 & 3.7 \\
\hline Difference & & 0.000 & 0.000 & 0.4 & 0.0 & 0.0 & 0.0 & 0.4 & 0.0 & 0.0 & 0.2 \\
\hline
\end{tabular}

kernel and a function of the human population density, which is then normalized so that the sum of the probabilities is equal to 1 . Although the absolute human population density, and more generally, human activities, differ between China and Europe, the model essentially describes the same process but adjusts the probabilities. Lastly, there is a time lag between the introduction of the nematode and its spread in China as well as in Portugal. This time lag is of the same order of magnitude in both countries ( 6 years in China compared to less than 9 years in Portugal; see Robinet et al. 2009 for Chinese data) and the radius of these new outbreaks is also roughly the same (111 vs. $150 \mathrm{~km}$; see Robinet et al. 2009 for the Chinese data). Although this pattern is relatively common, these similarities in term of magnitude also support our choice to apply the Chinese parameters in Europe.

Our model aims to identify the ports from which the pine wood nematode and pine wilt disease could spread rapidly if introduced in order to target surveillance and control measures. In this model, we are modelling large-scale processes but smallscale mechanisms, such as the dispersal capability of the European carrier beetle and the environmental conditions for the disease development, are still important to predict the potential spread with the accuracy required to draw conclusions at local scale.

This study provides scenarios for the spread of pine wood nematode and pine wilt disease based on separate introductions at the 200 main ports in Europe. These scenarios will help decision makers to identify the points which require higher surveillance and thus strengthen the control measures already implemented in Europe (see Appendix S3). Based on the spread simulations, the most important ports to monitor to prevent a rapid invasion of the disease are clearly those in Romania, Bulgaria, Croatia, Ukraine, Italy, Greece, Hungary, Slovakia 
and Slovenia. Assuming that containment of the current outbreak in Portugal is unsuccessful, an introduction to ports located in the likely range expansion of the disease (Spain and Southern France) may have little additional influence on the invasion situation in 2030. The most important ports to control to prevent the invasion of the pine wood nematode are located in Eastern and Northern Europe. Since the detection and eradication of the nematode seems very difficult, at least in areas where the symptoms do not appear (Økland et al. 2010), and containment and enforcement measures may not be sufficient effective to limit the spread of the disease (Japan and Portugal), then increasing surveillance at critical entry points mentioned above is fundamental in the future.

Although the pine wood nematode could theoretically be present without causing symptoms in Northern Europe because of unfavourable climatic conditions, this does not mean that these countries will not be affected by the possible invasion of the nematode. Embargoes against the importation of coniferous wood from North America (where the pine wood nematode is present however without causing substantial damage in native coniferous species) lead to important economic loss (Bergdahl 1988; Dwinell 1997). Therefore, the presence of the nematode in the absence of the disease in northern European countries, could still lead to serious economic impacts, not due to tree mortality, but due to loss of export markets.

From the different climate scenarios used in this study, climate warming could considerably increase the potential spread of pine wilt disease across Europe. The effects of climate warming will probably be more important in Europe than in China. With a temperature rise of $3^{\circ} \mathrm{C}$, the area where the temperature is suitable for the disease expression could expand by $40 \%$ in China (Robinet et al. 2009) while this area could more than double in Europe (23\% of the study area is potentially favourable for disease expression based on the 1950-2000 data, and it would reach $55 \%$ with a $3{ }^{\circ} \mathrm{C}$ increase). Indeed, the temperature in July would not reach the required thresholds in a large part of Western China because of a very high elevation $(>3,000 \mathrm{~m}$ asl). Consequently, with ongoing climate warming, the importance of preventing the additional introductions of the pine wood nematode will continue to increase.
Acknowledgments We gratefully acknowledge support for this work from the Forest Health Department (DSF) of the French Ministry of Food, Agriculture and Fisheries, the EU project PRATIQUE KBBE-2007-212459 (FP7 Project, Enhancements of pest risk analysis techniques; Baker et al. 2009) and RE-PHRAME KBBE.2010.1.4-09 (FP7 Project, Analysis of the potential of the pine wood nematode (Bursaphelenchus xylophilus) to spread, survive and cause pine wilt in European coniferous forests in support of EU plant health policy). We also thank Hugh Evans, Laurence BouhotDelduc, Hervé Jactel, Géraldine Roux, and Katja Gunia for discussions about this study, and Olivier Denux and Maxime Dupin for technical assistance with GIS.

Open Access This article is distributed under the terms of the Creative Commons Attribution Noncommercial License which permits any noncommercial use, distribution, and reproduction in any medium, provided the original author(s) and source are credited.

\section{References}

Anonymous (2007) Development of improved pest risk analysis techniques for quarantine pests, using pinewood nematode, Bursaphelenchus xylophilus, in Portugal as a model system. Final report of the EU project "Plant health risk and monitoring evaluation". Available at: http://www.forestresearch. gov.uk/website/forestresearch.nsf/ByUnique/INFD-7XRFX9 Accessed 26 March 2010

Baker RHA, Battisti A, Bremmer J et al (2009) PRATIQUE: a research project to enhance pest risk analysis techniques in the European Union. EPPO Bull 39:87-93

Bergdahl DR (1988) Impact of pine wood nematode in North America: present and future. J Nematol 20:260-265

Center for International Earth Science Information Network (CIESIN), Centro Internacional de Agricultura Tropical (CIAT) (2005) Gridded population of the world version 3 (GPWv3): population density grids. Palisades, NY: Socioeconomic Data and Applications Center (SEDAC), Columbia University. Available at http://sedac.ciesin. columbia.edu/gpw. Accessed 27 Jan 2009

Chang R, Chao J, Fan Y et al (1995) Investigation of the insect vector of pine wilt disease in Taïwan. Plant Prot Bull 37:448

Dropkin VH, Foudin A, Kondo E et al (1981) Pinewood nematode. A threat to US forests? Plant Dis 65:1022-1027

Dwinell LD (1997) The pinewood nematode: regulation and mitigation. Annu Rev Phytopathol 35:153-166

Elith J, Leathwick JR (2009) Species distribution models: ecological explanation and prediction across space and time. Annu Rev Ecol Evol Syst 40:677-697

Elith J, Graham CH, Anderson RP et al (2006) Novel methods improve prediction of species' distributions from occurrence data. Ecography 29:129-151

Evans HF, McNamara DG, Braasch H et al (1996) Pest risk analysis (PRA) for the territories of the European Union (as PRA area) on Bursaphelenchus xylophilus and its vectors in the genus Monochamus. EPPO Bull 26:199-249 
Evans S, Evans HF, Ikegami M (2008) Modeling PWNinduced wilt expression: a mechanistic approach. In: Mota M, Vieira P (eds) Pine Wilt disease: a worldwide threat to forest ecosystems. Springer, New York, pp 259-278

Gilbert M, Grégoire J-C, Freise J (2004) Long-distance dispersal and human population density allow the prediction of invasive patterns in the horse chestnut leafminer Cameraria ohridella. J Anim Ecol 73:459-468

Guisan A, Zimmermann NE (2000) Predictive habitat distribution models in ecology. Ecolo Modelling 135:147-186

Hellrigl KG (1971) Die bionomie der Europaischen Monochamus - arten (Coleopt., Cerambycid.) und ihre bedeutung fur die forst- und holzwirtschaft. Redia 52: 367-509

Hijmans RJ, Cameron SE, Parra JL et al (2005) Very high resolution interpolated climate surfaces for global land areas. Int J Clim 25:1965-1978

Hulme PE, Pyšek P, Nentwig W et al (2009a) Will threat of biological invasions unite the European Union? Science 324:40-41

Hulme PE, Roy DB, Cunha T et al (2009b) A pan-European inventory of alien species: rationale, implementation and implications for managing biological invasions. In: Handbook of alien species in Europe, ISBN: 978-1-40208279-5 e-ISBN: 978-1-4020-8280-1 Library of Congress Control number: $2008933943^{\circ} 2009$ Springer Science+Business Media BV www.europe-aliens.org/pdf/ chapter1.pdf. Accessed 14 May 2009

Humphry SJ, Linit MJ (1989) Tethered flight of Monochamus carolinensis (Coleoptera: Cerambycidae) with respect to beetle age and sex. Environ Entomol 18:124-126

IPCC (2007) Summary for policymakers. In: B Metz, OR Davidson, PR Bosch, R Dave, LA Meyer (eds) Climate change 2007: mitigation. Contribution of Working Group III to the fourth assessment report of the Intergovernmental Panel on Climate Change, Cambridge University Press, Cambridge, United Kingdom and New York, NY, USA

Kawabata K (1979) Dispersal of the Japanese pine sawyer, Monochamus alternatus, among small islands. In: Transaction of the 32nd Annual meeting of Kyushu Branch, the Japanese Forestry Society, pp 281-282

Kobayashi F, Yamane A, Ikeda T (1984) The Japanese pine sawyer beetle as the vector of pine wilt disease. Annu Rev Entomol 29:115-135

Kriticos DJ, Randall RP (2001) A comparison of systems to analyse potential weed distributions. In: Groves RH, Panetta FD, Panetta JG (eds) Weed risk assessment. CSIRO Publishing, Melbourne, pp 61-79

Lai Y (1998) The different effect of practising two strategic ways to control the pine wilt disease. In: Proceedings of International Symposium "Sustainability of pine forests in relation to pine wilt and decline", Tokyo (Japan, 27-28 Oct 1998)

Lai Y, Zhou Y, Yu L et al (1999) Cause of pine wilt disease infecting healthy pine forest. J Zhejiang For College 16:425-429

Lee SM, Choo HY, Park NC et al (1990) Nematodes and insects associated with dead trees, and pine wood nematode detection from the part of Monochamus alternatus. Korean J Appl Entomol 29:14-19
Liebhold AM, Tobin PC (2008) Population ecology of insect invasions and their management. Annu Rev Entomol 53:387-408

Linit MJ (1988) Nematode Vector relationships in the Pine wilt disease system. J Nematol 20:227-235

Linit M, Akbulut S (2003) Pine wood nematode phoresis: the impact on Monochamus carolinensis life functions. Nematol Monogr \& Persp 1:227-237

Linit MJ, Kondo E, Smith MT (1983) Insects Associated with the Pinewood Nematode, Bursaphelenchus-xylophilus (Nematoda, Aphelenchoididae), in Missouri. Environ Entomol 12:467-470

Lippitt CD, Rogan J, Toledano J et al (2008) Incorporating anthropogenic variables into a species distribution model to map gypsy moth risk. Ecol Model 210:339-350

Lobo JM, Jiménez-Valverde A, Hortal J (2010) The uncertain nature of absences and their importance in species distribution modelling. Ecography 33:103-114

Ma R-Y, Hao S-G, Kong W-N et al (2006) Cold hardiness as a factor for assessing the potential distribution of the Japanese pine sawyer Monochamus alternatus (Coleoptera: Cerambycidae). Ann For Sci 63:449-456

Mamiya Y (1972) Pine wood nematode, Bursaphelenchus lignicolus Mamiya and Kiyohara, as a causal agent of pine wilting disease. Rev Plant Prot Res 5:46-60

Mamiya Y (1984) The pine wood nematode. In: Nickle WR (ed) Plant and insect nematodes. Marcel Dekker, NewYork, pp 589-626

Meehl GA, Stocker TF, Collins WD et al (2007) Global climate projections. In: Solomon S, Qin D, Manning M, Chen Z, Marquis M et al (eds) Climate change 2007: the physical science basis. Cambridge University Press, Contribution of Working Group I to the Fourth Assessment Report of the intergovernmental panel on climate change. Cambridge, pp 747-845

Meentemeyer RK, Anacker BL, Mark W, Rizzo D (2008) Early detection of an emerging forest disease using dispersal estimation and ecological niche modelling. Ecol Appl 18:377-390

Mota MM, Braasch H, Bravo MA et al (1999) First report of Bursaphelenchus xylophilus in Portugal and in Europe. Nematology 1:727-734

Mota MM, Futai K, Vieira P (2009) Pine wilt disease and the pinewood nematode, Bursaphelenchus xylophilus. In: Ciancio A, Mukerji KG (eds) Integrated management of fruit crops and forest nematodes. Springer science, pp 253-274. doi:10.1007/978-1-4020-9858-1_11

Muirhead JR, Leung B, van Overdijk C et al (2006) Modelling local and long-distance dispersal of invasive emerald ash borer Agrilus planipennis (Coleoptera) in North America. Divers Distrib 12:71-79

Murray JD (2002) Mathematical biology i: an introduction. Interdisciplinary applied mathematics, 17, 3rd edn. Springer, New York

Økland B, Skarpaas O, Schroeder M, Magnusson C, Lindelöw A, Thunes K (2010) Is eradication of the pinewood nematode (Bursaphelenchus xylophilus) likely? An evaluation of current contingency plans. Risk Anal 30:1424-1439

Penas AC, Bravo MA, Naves P et al (2006) Species of Bursaphelenchus Fuchs, 1937 (Nematoda: Parasitaphelenchidae) and other nematode genera associated with insects 
from Pinus pinaster in Portugal. Ann Appl Biol 148:121-131

Pérez G, Díez JJ, Ibeas F et al (2008) Assessing pine wilt disease risk under a climate change scenario in Northwestern Spain. In: Bravo $\mathrm{F}$ et al (eds) Managing forest ecosystems: the challenge of climate change. pp, Springer Science, pp 269-282

Pimentel D, Zuniga R, Morrison D (2005) Update on the environmental and economic costs associated with alieninvasive species in the Unites-States. Ecol Econ 52:273-288

Pitt JPW, Worner SP, Suarez AV (2009) Predicting Argentine ant spread over the heterogeneous landscape using a spatially explicit stochastic model. Ecol Appl 19:1176-1186

Robinet C, Roques A, Pan H et al (2009) Role of human-mediated dispersal in the spread of the pinewood nematode in China. PLoS ONE 4(2):e4646. doi:10.1371/journal. pone. 0004646

Rodrigues JM (2008) National eradication programme for the pinewood nematode. In: Mota MM, Vieira PR (eds) Pine wilt disease: a worldwide threat to forest. Springer Science+Business Media BV. ISBN: 978-1-4020-8454-6, pp 5-14

Roques A, Rabitsch W, Rasplus J-Y et al (2009) Alien terrestrial invertebrates of Europe. In: Handbook of alien species in Europe. ISBN: 978-1-4020-8279-5 e-ISBN: 978-1-4020-8280-1 Library of Congress Control Number: $2008933943^{\odot} 2009$ Springer Science+Business Media BV

Roura-Pascual N, Bas JM, Thuiller W, Hui C, Krug RM, Brotons L (2009) From introduction to equilibrium: reconstructing the invasive pathways of the Argentine ant in a Mediterranean region. Glob Change Biol 15:2101-2115

Rutherford TA, Webster JM (1987) Distribution of pine wilt disease with respect to temperature in North America, Japan, and Europe. Can J For Res 17:1050-1059

Rutherford TA, Mamiya Y, Webster JM (1990) Nematodeinduced pine wilt disease: factors influencing its occurrence and distribution. For Sci 36:145-155

Shigesada N, Kawasaki K (1997) Biological invasions: theory and practice. In: Oxford series in ecology and evolution, Oxford University Press, Oxford

Sousa E, Bravo MA, Pires J et al (2001) Bursaphelenchus xylophilus (Nematoda; Aphelenchoididae) associated with
Monochamus galloprovincialis (Coleoptera; Cerambycidae) in Portugal. Nematology 3:89-91

Sousa E, Naves P, Bonifácio L et al (2002) Preliminary survey for insects associated with Bursaphelenchus xylophilus in Portugal. EPPO Bull 32:499-502

Suzuki K (2002) Pine wilt disease-a threat to pine forest in Europe. Dendrobiology 48:71-74

Takasu F (2009) Individual-based modeling of the spread of pine wilt disease: vector beetle dispersal and the Allee effect. Popul Ecol 51:399-409

Takasu F, Yamamoto N, Kawasaki K et al (2000) Modeling the expansion of an introduced tree disease. Biol Inv 2:141-150

R Development Core Team (2009) R: a language and environment for statistical computing. R Foundation for Statistical Computing, Vienna, Austria. ISBN 3-90005107-0, URL http://www.R-project.org

Togashi K (1990) A field experiment on dispersal of newly emerged adults of Monochamus alternatus (Coleoptera: Cerambycidae). Res Popul Ecol 32:1-13

Togashi K, Shigesada N (2006) Spread of the pinewood nematode vectored by the Japanese pine sawyer: modeling and analytical approaches. Popul Ecol 48:271-283

Tröltzsch K, Van Brusselen J, Schuck A (2009) Spatial occurrence of major tree species groups in Europe derived from multiple data sources. For Ecol \& Manag 257:294-302. doi:10.1016/j.foreco.2008.09.012

Václavík T, Meentemeyer RK (2009) Invasive species distribution modelling (iSDM): are absence data and dispersal constraints needed to predict actual distributions? Ecol Model 220:3248-3258

Work TT, McCullough DG, Cavey JF et al (2005) Arrival rate of non-indigenous insect species into the United-States through foreign trade. Biol Inv 7:323-332

Yang B (2004) The history, dispersal and potential threat of pine wood nematode in China. In: Mota $\mathrm{M}$ and Vieira $\mathrm{P}$ (eds) The pinewood nematode, Bursaphelenchus xylophilus. In: Brill, E. J Proceedings of an International Workshop, University of Evora, Portugal, August 20-22, 2001. Nematology monographs and perspectives, vol 1. Leiden, The Netherlands, pp. 21-24 